\title{
Przedsiębiorczość wybranych biur podróży prowadzonych przez brazylijską Polonię w Rio de Janeiro
}

\section{Entrepreneurship of Selected Travel Agencies Run by the Brazilian Polish Diaspora in Rio de Janeiro}

Streszczenie: Powstanie oraz intensywny rozwój przedsiębiorstw turystycznych, w szczególności biur podróży, wiązały się z żywiołowym rozwojem ruchu turystycznego oraz tworzeniem się zrębów rynku turystycznego w pierwszej połowie XIX w. Ówczesne natężenie ruchu turystycznego skłoniło osoby fizyczne do podejmowania działalności gospodarczej, która polegała na sprzedawaniu usług takich jak wyżywienie, nocleg czy transport, a także na przygotowywaniu kompleksowych ofert usług turystycznych. W artykule omówiona zostanie krótko historia Polonii w Brazylii, historia powstawania biur podróży na świecie oraz działalność biur podróży w Rio de Janeiro, prowadzonych przez brazylijską Polonię. Biura te w dużej mierze specjalizują się w obsłudze Polaków przybywających do Brazylii na wakacje. Badania, na wynikach których opiera się artykuł, prowadzone były w roku 2019, a dzięki danym z biur podróży opisane zostały kierunki turystyczne najczęściej wybierane przez Polaków przybywających do Brazylii i korzystających z ofert lokalnych biur podróży. W artykule scharakteryzowano dwa prężnie działające polskie biura w Rio de Janeiro: Brazylia Tour oraz Samba Smile Travel. Omówiona została oferta turystyczna tych biur podróży, liczba obsługiwanych przez nich klientów oraz specyfika funkcjonowania polskich biur podróży w Rio de Janeiro. Przedstawiona została również oferta wycieczek po mieście obsługiwanych w języku polskim przez lokalnych przewodników.

Abstract: The creation of touristic entrepreneurships and their further vivid development, especially
travel agencies, is linked to the intensive tourist traffic and bases of the tourist market in the first half
of the 19th century. The range and intensity of this traffic induced the natural persons' undertaking of
economic activities, such as providing accommodation, nourishment or transport, as well as preparation
of complex touristic proposals. The entrepreneurship of selected travel agencies in Rio de Janeiro run
by the Brazilian Polish diaspora will be discussed in this paper. These agencies are largely specialised
in tending to the Poles residing in Brazil for holidays. The research was conducted in 2019. Thanks to
the research data on the agencies, touristic directions most commonly chosen by the Poles coming to
Brazil and using the local travel agencies will be described. The profile of the largest and most intensively
operating Polish travel agencies in Rio de Janeiro, such as Brazylia Tour or Samba Smile Travel, will be 
outlined. Touristic offer of individual travel agencies, the number of customers and the idiosyncrasy of the Polish travel agencies in Rio de Janeiro will be discussed. The proposal of the city tours in Polish by the local guides will also be thoroughly analysed.

Słowa kluczowe: biuro podróży; Brazylia; Polonia; Rio de Janeiro; turystyka

Keywords: Brazil; Polish people; Rio de Janeiro; tourism; travel agencies

Otrzymano: 16 lutego 2020

Received: 16 February 2020

Zaakceptowano: 31 lipca 2020

Accepted: 31 July 2020

\section{Sugerowana cytacja/Suggested citation:}

Ziółkowska-Weiss, K. (2020). Przedsiębiorczość wybranych biur podróży prowadzonych przez brazylijską Polonię w Rio de Janeiro. Przedsiębiorczość - Edukacja [Entrepreneurship - Education], 16(2), 274-289. doi: 10.24917/20833296.162.22

\section{Wstęp}

$\mathrm{Na}$ całym świecie turystyka jest zjawiskiem stale zmieniającym się i najszybszej rozwijającą się działalnością, na co m.in. wskazują coroczne raporty Światowej Organizacji Turystyki Narodów Zjednoczonych (United Nations World Tourism Organization UNWTO). Wielowymiarowy charakter turystyki możemy rozpatrywać w pięciu aspektach: kulturowym, ekonomicznym, społecznym, psychologicznym i przestrzennym. Według K. Przecławskiego (1986) turystyka to: „całokształt zjawisk ruchliwości przestrzennej, związanych z dobrowolną, czasową zmianą miejsca pobytu, rytmu i środowiska życia oraz wejście w styczność osobistą ze środowiskiem odwiedzanym (przyrodniczym, kulturowym bądź społecznym)". Światowa Organizacja Turystyki w czasie międzynarodowej konferencji w Ottawie w 1991 r. podała następującą definicję turystyki: „turystyka obejmuje ogół czynności osób, które podróżują i przebywają w celach wypoczynkowych, służbowych lub innych, nie dłużej niż przez rok bez przerwy, poza swoim codziennym otoczeniem, z wyłączeniem wyjazdów, w których głównym celem jest działalność zarobkowa wynagradzana w odwiedzanej miejscowości” (za: Łukasiewicz, 2019: 105).

Powstanie oraz rozwój przedsiębiorstw turystycznych, w szczególności biur podróży wiązały się z żywiołowym rozwojem ruchu turystycznego oraz tworzeniem się zrębów rynku turystycznego w pierwszej połowie XIX w. Ówczesne natężenie ruchu turystycznego skłoniło osoby fizyczne do podejmowania działalności gospodarczej, która polegała na sprzedawaniu usług, takich jak: transport, nocleg czy wyżywienie a także na przygotowywaniu kompleksowych ofert usług turystycznych.

Pod wpływem postępującego w XX w. uprzemysłowienia oraz postępu technicznego i organizacyjnego sprzyjającego wzrostowi wydajności pracy, a także stopniowego skracania czasu pracy, wprowadzenia płatnych urlopów i wzrostu dochodów ludności doszło do znaczących zmian w strukturze konsumpcji, których wyrazem było ujawnienie się nowych potrzeb w zakresie turystyki i wypoczynku (Ziółkowska-Weiss, 2016). Nagłe zainteresowanie oraz możliwości finansowe potencjalnych turystów doprowadziły do powstania biur podroży, które zajęły się zaspokajaniem powstałych potrzeb, polegającym na tworzeniu ofert turystycznych i wypoczynkowych. 
W Polsce podmioty zajmujące się działalnością w zakresie organizacji oraz pośrednictwa w turystyce przyjęto nazywać biurami podróży. Nie zawsze było to pojęcie jednoznaczne. Na przestrzeni minionych dekad nazwa ta zmieniała się, podobnie jak zmieniały się najistotniejsze cechy i zakres aktywności biur podróży. Termin „biuro podróży” sformułowany został przez K. Eckemanna w 1930 r., który za biuro podróży uważał instytucję prowadzoną na zasadach gospodarki zarobkowej, która zajmuje się organizacją podróży i występuje w roli pośrednika między przedsiębiorstwem komunikacyjnym a samym klientem (Konieczna-Domańska, 1999).

Dzięki biurom podróży, które w dużej mierze pomagają zorganizować i zaplanować podróż turystów, następuje rozwój turystyki. Pomimo powszechnego dostępu do internetu oraz możliwości szybkiego zaplanowania podróży za pomocą dostępnych w sieci informacji turystycznych, wciąż bardzo dużo podróżnych nie jest w stanie zrealizować swoich planów bez pomocy biur podróży.

Celem niniejszego artykułu jest omówienie działalności biur podróży prowadzonych przez Polonię w Rio de Janeiro i obsługujących przede wszystkim osoby przyjeżdżające do Brazylii na wakacje z Polski. Brazylia jest w naszym kraju postrzegana jako kraj odległy i niebezpieczny, w którym trzeba posługiwać się językiem portugalskim. Dlatego wielu naszych rodaków ma obawy przed zorganizowaniem tam indywidualnego wypoczynku i korzysta z pomocy i oferty miejscowych biur podróży, zwłaszcza jeśli chodzi o jednodniowe fakultatywne wycieczki po mieście. Pewność, iż zostaną obsłużeni w języku polskim, oraz poczucie bezpieczeństwa i świadomość, że podczas wycieczki opiekować się nimi będzie osoba polskiego pochodzenia to główne powody, dla których turyści z Polski decydują się na skorzystanie z ofert turystycznych lokalnych biur podróży prowadzonych przez Polonię.

\section{Polonia w Brazylii oraz Rio de Janeiro}

Pierwsi polscy osadnicy przybyli do Brazylii w połowie XIX w. Główna fala imigracji miała natomiast miejsce pod koniec XIX w. (była to tzw. gorączka brazylijska) oraz na początku XX w. Początkowo byli to głównie chłopi, którzy korzystali z oferty rządu brazylijskiego, subsydiującego osadnictwo rolnicze na południu kraju. Otrzymywali oni darmową ziemię pod uprawę oraz wsparcie finansowe. Do 1939 r. przybyło do Brazylii ok. 150000 osób (Brzozowski, 2008).

Z. Malczewski pisze: „Emigranci zabrali ze sobą za ocean do Brazylii obraz Polski, którą opuszczali z różnych powodów. Zabrali ze sobą także dziedzictwo naszej kultury, tradycji, zwyczajów" (Malczewski, 1995: 93).

Polacy osiedleni w różnych rejonach Brazylii, ich przodkowie i potomkowie przyczynili się do stworzenia wielokulturowej społeczności (Kmiecik, 2016). Nie zapominali jednak o swoich przodkach oraz o kraju, z którego pochodzili. W swoim codziennym postępowaniu starali się wprowadzać na terenie Brazylii polskie zwyczaje oraz polskie symbole narodowe. Szczególnie widoczne było to w przypadku tradycji religijnych. Polacy osiedlający się w Brazylii często ustawali przydrożne krzyże i kapliczki, które stały się naturalnym brazylijskim krajobrazem, co szczególnie widoczne jest w okolicach Kurytyby.

Brazylia była pierwszym państwem Ameryki Łacińskiej, które w 1918 r. uznało niepodległość Polski. Związki między oboma narodami mają jednak znacznie dłuższą historię niż stosunki dyplomatyczne. Pojedyncze osoby z ziem polskich przenikały do Brazylii 
już w okresie kolonialnym, a po roku 1869 wychodźstwo przybrało charakter zorganizowany i masowy. Trzonem emigracji była ludność wiejska: bezrolni chłopi, robotnicy rolni, wiejscy rzemieślnicy itp. W nowej rzeczywistości polscy emigranci potrafili się zaaklimatyzować; powszechnemu awansowi społecznemu towarzyszyły procesy asymilacji i akulturacji. Nie zrywając więzów z krajem pochodzenia, przyjmowali również elementy kultury kraju osiedlenia. Dzięki temu stali się ważnym łącznikiem w stosunkach politycznych, gospodarczych i kulturalnych pomiędzy Brazylią a Polską (Mazurek, 2018).

Polskie czynniki rządowe, wobec dużego bezrobocia w miastach oraz przeludnienia na wsi polskiej, wspierały emigrację do Brazylii. Służył temu także układ w sprawie imigracji zawarty 19 lutego 1927 r. pomiędzy Urzędem Emigracyjnym w Warszawie a Departamentem Pracy stanu São Paulo. Łącznie w latach 1919-1939 do Brazylii wyjechało z Polski ponad 41 tys. osób, z czego znaczny odsetek stanowili przedstawiciele mniejszości narodowych, głównie Żydzi i Ukraińcy. W dużej części była to emigracja zorganizowana i kierowana przez instytucje prywatne i państwowe, rozwijające się w Polsce za sprawą ruchu kolonialnego (Mazurek, 2006). Emigrantów przewoziła m.in. powstała w $1934 \mathrm{r}$. polsko-duńska spółka akcyjna Gdynia-Ameryka Linie Żeglugowe (GAL), która posiadała swoje przedstawicielstwo także w Rio de Janeiro.

Narodowość to termin odnoszący się do kraju pochodzenia. Często bywa on używany jako bliski słowu „kultura”. Jest to odzwierciedlenie więzi łączącej kulturę i naród. Kultura sprawia, że łatwiej żyje nam się w danej grupie społecznej. Ściśle wiąże się z czynnikami środowiskowymi, cywilizacyjnymi, demograficznymi. Poczucie odrębności względem innych krajów kształtują: język, pochodzenie, świadomość narodowa, znajomość historii narodu, więzy krwi, dziedzictwo kulturowe, symbole narodowe (Kula, 2001).

Istnienie licznej społeczności polskiej w Brazylii było dla polskich naukowców, podróżników i pisarzy inspiracją do podejmowania tematyki brazylijskiej. Jej owocem jest ogromna liczba prac naukowych, reportaży, pamiętników, opowiadań i powieści, opisujących nie tylko warunki życia polskich osadników, ale także egzotykę, piękno i bogactwo przyrody tego kraju.

Dużym ośrodkiem polskiej kultury i tradycji w Brazylii poza miastem Kurytyba jest Rio de Janeiro, gdzie m.in. 11 listopada 1992 r. (w dniu Narodowego Święta Niepodległości Polski) miała miejsce inauguracja rozpoczęcia działalności Brazylijskiego Instytutu Kultury Polskiej. Wydarzenie to odbyło się w Brazylijskiej Akademii Literatury. Instytut powstał na mocy umowy, która zapewniała o wzajemnej współpracy rządy Polski i Brazylii oraz o możliwości szerzenia kultury polskiej w Brazylii. Jak napisał Malczewski (1995), głównym celem powstałej jednostki jest „rozpowszechnianie kultury, sztuki, nauki, literatury, muzyki, teatru, kinematografii i sztuk pięknych, muzeologii, architektury, folkloru, rzemiosła, ludowych tradycji, a nade wszystko języka polskiego" (Malczewski, 1995: 102). Do zadań Instytutu należą także przygotowywanie przedstawień teatralnych, występów muzycznych i wystaw, utrzymywanie kontaktów z ośrodkami kultury, literatury, sztuki, zachęcanie do wymiany uniwersyteckiej oraz rozwój nauczania języka polskiego.

W dzisiejszej Brazylii nie istnieją statystyki, które mówiłyby o liczebności grupy etnicznej pochodzenia polskiego. Niezależnie od szacunków, których rząd wielkości wynosi od $1 \mathrm{mln}$ do $3 \mathrm{mln}$, obecni potomkowie polskich emigrantów w Brazylii żyją już w zupełnie w innej rzeczywistości i mogą poszczycić się wieloma osiągnięciami.

Intensyfikacja życia kulturalnego potomków polskich imigrantów w Brazylii oraz współpraca instytucji polonijnych $\mathrm{z}$ instytucjami polskimi nasilały się od początku 
lat 90. XX w. W 1990 r. zostały założone dwie nowe organizacje: POLBRAS i BRASPOL, z których do dziś przetrwała tylko ta ostatnia. BRASPOL (Federacja Stowarzyszeń Polonijnych w Brazylii) zespala obecnie ponad 360 jednostek polonijnych rozrzuconych po całym kraju, przyczyniając się do ich zbliżenia i zaktywizowania działań. Ponadto popularność i wysoki poziom artystyczny osiągnęły polskie zespoły folklorystyczne, czego dowodem jest ich częsty udział w przeróżnych, także międzynarodowych, festiwalach. Niezwykle istotna dla zachowania tożsamości jest też rola polskiego duchowieństwa i licznych zgromadzeń zakonnych, pełniących posługę religijną wśród Polonii. W skupiskach Brazylijczyków polskiego pochodzenia prowadzona jest bogata działalność kulturalno-społeczna: kultywuje się polskie tradycje i zwyczaje, organizuje kursy języka polskiego, celebruje polskie święta narodowe i kościelne. Dowodem na to jest chociażby wyświęcenie 25 stycznia 2020 r. polskiego księdza Zdzisława Stanisława Błaszczyka na biskupa pomocniczego Rio de Janeiro.

Również działalność biur podróży w Rio de Janeiro, takich jak Samba Smile Travel czy Brazil Tour, prowadzonych przez Polonię, jest stałym akcentem polskości na brazylijskiej ziemi.

\section{Historia powstawania biur podróży oraz definicja biura podróży}

Biura podróży odgrywają obecnie znaczną rolę w dystrybucji produktu turystycznego, który stanowi ofertę ich sprzedaży. Są one głównym pośrednikiem między klientem-turystą a dobrami, towarami i usługami stanowiącymi produkt turystyczny. Jednocześnie biura podróży w większości są ściśle związane z obszarami generującymi ruch turystyczny.

Do XIX w. turystyka miała charakter elitarny. Podróżowali głównie ludzie należący do wąskiego kręgu arystokracji i ziemiaństwa. Jednak migracje ludności poza obszar stałego miejsca zamieszkania zdarzały się już od najdawniejszych czasów. Związane były one głównie z ekspansją terytorialną, handlem, dyplomacją, a także indywidualnymi potrzebami, które wynikały z celów o charakterze religijnym, zdrowotnym czy wypoczynkowym.

Procesy społeczne i gospodarcze zachodzące w XIX w. (a więc rozwój przemysłu, rozwój środków transportu, urbanizacja, podniesienie poziomu życia, większa ilość wolnego czasu, wzrost ogólnej świadomości itd.) przekształciły turystykę ze zjawiska o mało znaczącym i rzadko występującym fenomenie w zjawisko masowe, pociągające za sobą wiele skutków gospodarczych, społecznych i kulturowych.

Powstanie i dalszy intensywny rozwój przedsiębiorstw turystycznych, w szczególności biur podróży, wiązały się z gwałtownym rozwojem ruchu turystycznego oraz tworzeniem się zrębów rynku turystycznego w pierwszej połowie XIX w. (Rapacz, 2007). Natężenie tego ruchu skłoniło osoby fizyczne do podjęcia decyzji o zakładaniu działalności gospodarczej, która polegała na sprzedawaniu usług związanych z turystyką, takich jak: wyżywienie, nocleg czy transport, ale i na przygotowywaniu kompleksowych ofert usług turystycznych.

W Polsce podmioty zajmujące się działalnością w zakresie organizacji i pośrednictwa w turystyce określa się mianem biur podróży. Nie zawsze było to pojęcie jednoznaczne i zmieniało się ono na przestrzeni minionych dekad podobnie jak zmieniały się najistotniejsze cechy i zakres aktywności biur podróży.

Pojęcie biura podróży sformułowane zostało przez K. Eckemanna w 1930 r. Za biuro 
podróży uznał on instytucję prowadzoną na zasadach gospodarki zarobkowej, która zajmuje się organizacją podróży i występuje w roli pośrednika między klientem a przedsiębiorstwem komunikacyjnym (Konieczna-Domańska, 1999).

Z kolei P. Legler określił biuro podróży jako „przedsiębiorstwo służące jedynie zawodowemu pośredniczeniu przy organizowaniu podróży osobom trzecim lub zajmujące się organizowaniem imprez turystycznych we własnym imieniu” (Legler, 1950: 79-80).

Kolejne definicje wskazywały na szerszy zakres działalności omawianych podmiotów gospodarczych. Według R. Łazarka (2002), biuro podróży to „przedsiębiorstwo turystyczne, którego działalność może rozciągać się od współdziałania w urzeczywistnianiu podróży (np. sprzedaż biletów komunikacyjnych, miejsc noclegowych), aż do organizowania i sprzedaży standardowych wycieczek zryczałtowanych, w których wszystkie poszczególne elementy występują łącznie” (Konieczna-Domańska, 2008: 16).

Jak podaje I. Michalska-Dudek (2017), chociaż istnieje wiele definicji biura podróży i pojęcie to jest stosowane $\mathrm{w}$ językach obcych (np. travel agency $\mathrm{w}$ języku angielskim, reisebüro $\mathrm{w}$ języku niemieckim czy l'agence de voyages $\mathrm{w}$ języku francuskim) oraz $\mathrm{w}$ praktyce gospodarczej, w ustawodawstwie polskim ono nie występuje. A zatem termin „biuro podróży" stosuje się w odniesieniu do podmiotów, które zajmują się działalnością z zakresu organizacji i pośrednictwa w turystyce jako jedynym bądź głównym przedmiotem swej działalności.

Rynek biur podróży określa się również mianem rynku usług organizatorskich i pośredniczych. Obejmuje on: po stronie podaży - podmioty zajmujące się pośredniczeniem przy sprzedaży różnych usług turystycznych i procesem organizowania oraz sprzedaży usług oferowanych najczęściej w postaci pakietu świadczeń; po stronie popytu - grupę aktualnych i potencjalnych nabywców o wysokim poziomie zróżnicowania, a także o różnych turystycznych potrzebach. Podmioty organizacji i pośrednictwa pojawiły się na rynku turystycznym w XIX w. Od tego czasu datuje się ich rozwój oraz systematyczny wzrost znaczenia w obsłudze ruchu turystycznego (Konieczna-Domańska, 2008: 9).

Wzrost liczby osób, które podejmują podróże turystyczne i zgłaszają popyt na związane z nimi świadczenia, przyczynił się do stwarzania ofert dla indywidualnych turystów. W konsekwencji doprowadziło to do osiągania przez biura podróży zysków pieniężnych. Już na początku XIX w. zaczęły powstawać pierwsze instytucjonalne formy świadczenia usług pośrednictwa i organizacji, które związane były z masową emigracją obywateli wielu państw europejskich. Tak zwane agencje podróży prowadzone były wówczas przez maklerów okrętowych oraz armatorów. Zajmowały się one głównie dostarczeniem niezbędnych dokumentów podróży oraz sprzedażą biletów okrętowych.

Choć źródła literaturowe wśród najstarszych na świecie biur podróży wymieniają powstałą w 1758 r. - brytyjską firmę Cox \& Kings (Andrews, 2007; Singh, 2008), to jednak powstanie pierwszej instytucjonalnej formy świadczenia usług związanych z odbywaniem podróży datuje się dopiero na połowę XIX w., kiedy nastąpił wzrost aktywności turystycznej. Przełomowy był rok 1841, kiedy to T. Cook zorganizował wycieczkę kolejową na trasie Leicester-Lughborough. Fakt ten w literaturze przedmiotu uważa się za narodziny pierwszego biura turystycznego, choć już w starożytnym Rzymie kancelaria cesarska dysponowała Państwowym Biurem Podróży (Officium de Facere Evectionem). Z usług Towarzystwa Cooka poza Brytyjczykami korzystali również mieszkańcy wielu innych państw, nie tylko europejskich. W roku 1876 powstała w Anglii firma Wagons Lits, która połączyła się w 1929 r. z Towarzystwem Cooka (Grzelka, 1996). 
W innych krajach biura podróży tworzyły się w różnych okresach. Drugim znaczącym biurem podróży drugiej połowy XIX w. było założone w 1863 r. w Berlinie biuro C. Stangena, uważanego za niemieckiego pioniera zorganizowanych podróży. Stangen organizował zagraniczne podróże, m.in. wycieczki dookoła świata, a także wyjazdy na światowe wystawy, które odbywały się w Paryżu. Jego klientami byli głównie architekci, bankierzy, kupcy, rentierzy, artyści, jak również bogaci przemysłowcy, urzędnicy, ministrowie, a nawet książęta. Biuro Stangena jako pierwsze wprowadziło na rynek tzw. kupony hotelowe oraz specjalny system biletowy, który polegał na połączeniu biletu kolejowego z biletem linii okrętowych. Na ówczesne czasy był to precedens na rynku konsumpcyjnym.

Kolejne biura powstały w Szwecji, Szwajcarii i w Rzymie (Warszyńska, Jackowski, 1979). W tabeli 1 podano pierwsze biura podróży powstałe w XIX w.

Tabela 1. Pierwsze biura podróży powstałe w XIX w.

\begin{tabular}{|c|c|c|}
\hline Kraj & Nazwa biura & $\begin{array}{c}\text { Rok } \\
\text { założenia }\end{array}$ \\
\hline Anglia & $\begin{array}{l}\text { Thomas Cook, Londyn } \\
\text { FramesTours Ltd, Londyn } \\
\text { Polytechnic Tours, Londyn } \\
\text { Sir Henry Lunn Ltd, Londyn }\end{array}$ & $\begin{array}{l}1841 \\
1881 \\
1888 \\
1892\end{array}$ \\
\hline Niemcy & $\begin{array}{l}\text { Reisenbüro Rominger, Stuttgart } \\
\text { Karl Riesel, Berlin } \\
\text { Carl Stangen, Berlin } \\
\text { Adolf Hessel, Drezno } \\
\text { Internationale Rb Schenker \& Co, Monachiun }\end{array}$ & $\begin{array}{l}1842 \\
1854 \\
1863 \\
1863 \\
1889\end{array}$ \\
\hline Szwecja & $\begin{array}{l}\text { Nyman und Schulz, Sztokholm } \\
\text { S.J. Reisebuero, Sztokholm }\end{array}$ & $\begin{array}{l}1861 \\
1889\end{array}$ \\
\hline Szwajcaria & Reiseburo Zwilchanbart & 1834 \\
\hline USA & $\begin{array}{l}\text { Raymond and Whitcimb, Boston } \\
\text { Carton Travel Bureau, Chicago }\end{array}$ & $\begin{array}{l}1879 \\
1899\end{array}$ \\
\hline Włochy & Agenzia Viaggi Massimiliano Chiari, Rzym & 1878 \\
\hline Holandia & Lissone Lindemann, Haga & 1880 \\
\hline Norwegia & Bennett, Oslo & 1850 \\
\hline Belgia & $\begin{array}{l}\text { Voyages Geurts, Bruksela } \\
\text { Voyages Dumoulin, Bruksela }\end{array}$ & $\begin{array}{l}1884 \\
1893\end{array}$ \\
\hline Francja & $\begin{array}{l}\text { Agence Lubin, Paryż } \\
\text { Voyages Le Bourgeois, Paryż } \\
\text { Compagnie Internationale des Wagon-Lits, Paryż }\end{array}$ & $\begin{array}{l}1874 \\
1893 \\
1876\end{array}$ \\
\hline
\end{tabular}

Źródło: opracowanie własne na podstawie: Konieczna-Domańska (2008: 96-97)

Przedmiotem działalności biur podróży w drugiej połowie XIX w. było tworzenie pakietów kompleksowej obsługi podróży. Przedsiębiorstwa nie tylko korzystały wtedy z kursów rozkładowych pociągów i statków, lecz także same zaczęły organizować specjalne przewozy turystyczne czy pociągi przygotowane do konkretnej podróży. Zaczęto czarterować prywatne statki morskie i rzeczne, które dowoziły turystów do celu. W połowie $\mathrm{XX}$ w. zauważalne stało się rozdzielenie działalności organizatorskiej i pośrednictwa, co 
w praktyce oznaczało powstawanie wyspecjalizowanych podmiotów, świadczących usługi z zakresu organizacji imprez i zajmujących się pośrednictwem w turystyce (Byszewska-Dawidek, Łopaciński, 2013).

W okresie międzywojennym zaczęto zauważać dążenie przewoźników, zwłaszcza kolejowych, do zapewnienia sobie powiązań z podmiotami obsługi podróży turystycznych. Przejawiało się to nie tylko w otwieraniu własnych, prywatnych biur podróży i łączeniu się z biurami, które już istniały, ale także w nawiązywaniu kontaktów agencyjnych z niezależnymi biurami podróży. Prawo przedstawicielstwa stało się dla nich jednym z głównych rodzajów działalności usługowej. W kolejnych latach biura podróży rozszerzały swoją ofertę usług turystycznych o nowe propozycje podróży zorganizowanych oraz o nowe formy obsługi. Oprócz dalszego, szybkiego rozwoju pociągów turystycznych, charakterystyczny był rozwój pakietów autobusowych, a w kolejnym etapie - wykorzystanie samolotów do przewozu turystów.

Na obecny kształt rynku podmiotów organizacji i pośrednictwa turystycznego wpłynęły przede wszystkim procesy, które zaszły po II wojnie światowej, zwłaszcza w rozwiniętych krajach kapitalistycznych (proces racjonalizacji wielkości przedsiębiorstwa turystycznego i jego kooperacji z innymi branżami). Zadecydowały o tym rozmiary ruchu i popytu turystycznego oraz intensywny rozwój gospodarczy tych krajów. Po II wojnie światowej zaczął stopniowo przybierać na sile proces rozchodzenia się usług pośrednictwa turystycznego i organizacji. Przejawiało się to głównie w powstawaniu specjalistycznych firm zajmujących się organizowaniem podróży oraz dużej liczby agentów podróży, którzy przede wszystkim zajmowali się pośredniczeniem w sprzedaży usług turystycznych. Tabela 2 przedstawia poszczególne etapy rozwoju podmiotów świadczących usługi pośrednictwa i organizacji w turystyce.

Tabela 2. Etapy rozwoju podmiotów świadczących usługi pośrednictwa i organizacji w turystyce

\begin{tabular}{|l|l|}
\hline \multicolumn{1}{|c|}{ Okres } & \multicolumn{1}{|c|}{ Formy i rodzaje działalności usługowej } \\
\hline Początek XIX w. & $\begin{array}{l}\text { Biura emigracyjne prowadzone przez amatorów i maklerów } \\
\text { okrętowych zajmujących się sprzedażą biletów okrętowych } \\
\text { oraz innych dokumentów podróży }\end{array}$ \\
\hline Druga połowa XIX w. & $\begin{array}{l}\text { Samodzielne biura emigracyjne prowadzące agencyjną sprzedaż } \\
\text { biletów okrętowych na rzecz wielkich armatorów } \\
\text { oraz wyspecjalizowane wielofunkcyjne biura podróży } \\
\text { pośredniczące w sprzedaży biletów komunikacyjnych, rezerwacji } \\
\text { noclegów, a także podróżach zorganizowanych }\end{array}$ \\
\hline Początek XX w. & $\begin{array}{l}\text { Wyspecjalizowane w pośrednictwie oraz organizacji podróży } \\
\text { wielofunkcyjne biura podróży }\end{array}$ \\
\hline Okres międzywojenny & $\begin{array}{l}\text { Rozszerzanie oferty przez wyspecjalizowane, wielofunkcyjne biura } \\
\text { podróży, powiązane również z kolejami }\end{array}$ \\
\hline Lata 40. i 50. XX w. & $\begin{array}{l}\text { Dywersyfikacja oferty wyspecjalizowanych, wielofunkcyjnych biur } \\
\text { podróży średniej i małej wielkości }\end{array}$ \\
\hline Lata 60. i następne XX w. & $\begin{array}{l}\text { Powstawanie specjalistycznych touroperatorów - koncentracja } \\
\text { pionowa i pozioma, monopolizacja rynku przez największych } \\
\text { z nich oraz wydzielenie wyspecjalizowanych detalicznych agencji } \\
\text { podróży pośredniczących w sprzedaży usług cząstkowych } \\
\text { i zorganizowanych pakietów usług }\end{array}$ \\
\hline
\end{tabular}

Źródło: opracowanie własne na podstawie: Konieczna-Domańska (2008: 128) 
Chociaż intensywność przemian rynku usług pośrednictwa i organizacji pozostawała w zależności od stopnia rozwoju konkretnego rynku turystycznego (a więc potencjału popytu oraz podaży usług turystycznych), jak też od systemu ekonomicznego, w którym funkcjonował dany rynek, to różna była skala zmian zachodzących na poszczególnych rynkach krajowych (Konieczna-Domańska, 2008).

\section{Przebieg, metody oraz zakres czasowy i przestrzenny badań empirycznych}

Zasadniczym obszarem prowadzonych badań było Rio de Janeiro. Badania terenowe prowadzone były w dniach 21-30 stycznia 2019 r. Podczas badań zastosowano metodę jakościową, polegającą na przeprowadzeniu wywiadów z właścicielami i pracownikami dwóch biur podróży prowadzonych na terenie objętym badaniem. Były to pogłębione indywidualne wywiady w biurze podróży Samba Smile Travel oraz Brazylia Tour.

Na podstawie przeprowadzonych rozmów przeanalizowano oferty najczęściej wybierane przez turystów korzystających z badanych biur podróży. Autorka niniejszego opracowania dowiedziała się także, jaka jest specyfika funkcjonowania polskich biur podróży w Rio de Janeiro, ilu turystów rocznie jest obsługiwanych przez te biura, ile kosztują poszczególne wycieczki oraz jakie przedsiębiorcze plany na przyszłość mają właściciele opisywanych turystycznych podmiotów gospodarczych.

Badania jakościowe początek swój czerpią z badań etnograficznych, które są zakorzenione w antropologii. W stosunku do badań ilościowych badania te koncentrują się na dogłębnej analizie badanych zjawisk. W badaniach jakościowych największy nacisk kładzie się na to, aby za pomocą specjalnych technik lepiej i dokładniej te zjawiska zrozumieć. Badacz powinien patrzeć na otaczającą rzeczywistość niejako oczami badanych, starając się przy tym nie sugerować z góry przyjętymi przez siebie przypuszczeniami lub schematami rozumowania (Alejziak, 2005). W takich badaniach nie chodzi o ilościowe ujmowanie danych na temat przedmiotu badań, ale o uzyskanie jakościowo „najlepszych” informacji, które poszerzą stan wiedzy o badanym zjawisku. W badaniach ilościowych zazwyczaj rozpatrywane są zjawiska już dosyć dobrze znane i określone, natomiast badania jakościowe często dostarczają zupełnie nowej, pionierskiej wiedzy. Zakłada się, że w badaniach ilościowych odpowiedzi najczęściej są podane, np. w kwestionariuszu ankiety, a respondenci zaznaczają jedną $\mathrm{z}$ nich. W badaniach jakościowych odpowiedzi natomiast uzyskiwane są od samych badanych osób w taki sposób, że badacz nie zakłada z góry, jakie one będą.

Takie podejście w naukach humanistycznych umożliwia uzyskanie nietypowych danych, pozwala na spojrzenie na analizowane zagadnienie $\mathrm{z}$ innej perspektywy. W badaniach jakościowych celem nie jest uzyskanie odpowiedzi na pytanie „Ile?”, ale „Dlaczego? i „Jak?”. Na przykład o ile w badaniach ilościowych danego produktu turystycznego mierzy się, jak często jest on kupowany i na ile podoba się on klientom, o tyle w badaniach jakościowych otrzymuje się informacje o tym, dlaczego klienci go wybierają oraz co sprawia, że to właśnie nim się interesują (Alejziak, 2008).

Badania jakościowe są dominującą metodą w antropologii, socjologii, psychologii, a także organizacji i zarządzaniu. Natomiast w naukach przyrodniczych opierają się najczęściej na porównaniu właściwości lub zachowania obiektu badań ze znanymi wzorcami (Ziółkowska-Weiss, 2019).

Badania jakościowe mają pewne wady. W przeciwieństwie do badań ilościowych są mało usystematyzowane i raczej nie stosuje się w nich wnioskowania statystycznego. Ich 
wadą jest też to, że zazwyczaj nie pozwalają na szerokie uogólnienia i generalizacje (np. na całą populację), ponieważ nie są reprezentatywne, a także mogą być podatne na subiektywną i nie do końca obiektywną ocenę badacza. Badania jakościowe są też zazwyczaj bardziej czasochłonne w realizacji niż badania ilościowe (Jasiński, Kowalski, 2007). W badaniach jakościowym w zasadzie nie występuje pomiar, a ich celem jest stworzenie typologii obserwowanych przedmiotów badań i opisanie relacji między nimi.

\section{Działalność polskich biur podróży w Rio de Janeiro}

Jak już powiedziano, celem niniejszego artykułu jest przedstawienie biur podróży w Rio de Janeiro, które prowadzone są przez mieszkającą tam Polonię. Na terenie objętym badaniem swoją działalność prowadzą dwa takie biura podróży. Jedno z nich to Samba Smile Travel, a drugie - Brazylia Tour.

Poza wymienionymi podmiotami turystycznymi w Rio de Janeiro pracują indywidualni przewodnicy, którzy obsługują jednodniowe wycieczki w języku polskim i ogłaszają się w internecie. Oferty takich wycieczek są bardzo zróżnicowane zarówno pod względem ich długości (od 2-10 godz.), jak i pod względem kosztów. Podczas badań terenowych i rozmów z pięcioma przewodnikami oferującymi swoje usługi w mieście Rio de Janeiro w języku polskim autorka uzyskała informację, że cena wycieczki przede wszystkim zależy od liczby osób w grupie. Im większa liczna uczestników wycieczki, tym cena jest niższa. Przykładowo, za trwającą 3 godz. wycieczkę na Głowę Cukru wraz z opieką polskiego przewodnika w trzyosobowej grupie koszt takiej wycieczki wynosi ok. $180 \mathrm{zł}$ za osobę (z biletami wstępu), a w grupie dziesięcioosobowej - ok. 130 zł. Osoby oferujące takie usługi to głównie Polacy, którzy na stałe mieszkają w Polsce, a do Rio de Janeiro przyjeżdżają głównie w sezonie wakacyjnym i wysokim sezonie turystycznym w Brazylii (listopad-luty). W tym okresie pracują jako przewodnicy oferujący przede wszystkim polską opiekę językową podczas zwiedzania przez turystów miasta, a po sezonie w Brazylii wracają z powrotem do ojczystego kraju, do Polski.

Autorce artykułu udało się dotrzeć tylko do jednego Brazylijczyka mieszkającego na stałe w Rio de Janeiro, który oferuje swoje usługi przewodnickie w języku polskim. Pozostałe osoby przybywające na sezon turystyczny z Polski oprowadzają turystów w języku polskim, ale także w języku angielskim (głównie Amerykanów, Holendrów oraz osoby przyjeżdzające do Brazylii ze Skandynawii).

W tabeli 3 zestawiono przykładowe oferty wycieczek w Rio de Janeiro w języku polskim, które dostępne są na ogólnych internetowych stronach i portalach społecznościowych.

Tabela 3. Internetowa oferta jednodniowych wycieczek po Rio de Janeiro w języku polskim

\begin{tabular}{|l|c|c|}
\hline \multicolumn{1}{|c|}{ Rodzaj wycieczki } & $\begin{array}{c}\text { Długość } \\
\text { trwania }\end{array}$ & $\begin{array}{c}\text { Najniższa cena } \\
\text { w zl/os. }\end{array}$ \\
\hline Wycieczka do pomnika Chrystusa Odkupiciela & $2-3$ godz. & 80 \\
\hline Dzień w Rio: pomnik Chrystusa, Głowa Cukru, Selaron, lunch & $8-9$ godz. & 440 \\
\hline Zwiedzanie Głowy Cukru & $2-3$ godz. & 130 \\
\hline Wycieczka do faveli Rocinha & 4 godz. & 165 \\
\hline Muzeum Jutra, MAR i Aquarium & 6 godz. & 130 \\
\hline Zwiedzanie faveli Santa Marta & 2 godz. & 140 \\
\hline Santa Teresa, Lapa, schody Selaron & 3 godz. & 150 \\
\hline
\end{tabular}

Źródło: opracowanie własne na podstawie przeprowadzonych badań 
Jak zapewniają przewodnicy, wycieczkę wystarczy zamówić dzień wcześniej, jednak może to wiązać się z wyższymi kosztami usługi, niż gdyby wycieczka zamówiona była $\mathrm{z}$ kilkunastodniowym wyprzedzeniem.

\section{Działalność biura podroży Samba Smile Travel oraz Brazylia Tour}

Właścicielkami i założycielkami Samba Smile Tavel są dwie Polki: Anna Sadowska i Dagmara Szkudłapska-Ferreira. Obie ukończyły kurs przewodników po Rio de Janeiro, Brazylii i krajach Ameryki Południowej. Obie mieszkają od wielu lat w Rio de Janeiro i bardzo dobrze znają to miasto. Poza usługami przewodnickimi pomagają zorganizować nocleg czy transport w Brazylii.

Autorka artykułu, przeprowadzając dogłębny wywiad z Dagmarą Szkudlapską-Ferreirą, dowiedziała się, że biuro obsługuje głównie osoby, które przyjeżdżają z Polski na wakacje do Brazylii (85\% klientów). Pozostałą część klientów stanowią przede wszystkim turyści z USA. W wysokim sezonie, który trwa od listopada do marca, biuro obsługuje swoich klientów sześć dni w tygodniu, w pozostałe miesiące - trzy dni w tygodniu. W miesiącach poza sezonem właścicielki przygotowują programy na kolejny sezon, robią kosztorysy, reklamy, uaktualniają stronę internetową. Podróżują również do Polski, głównie do Krakowa i Warszawy, w celu przedstawienia swoich ofert polskim firmom, które niejednokrotnie korzystały z ofert Samba Smile Travel w ramach wyjazdów incentive travel organizowanych dla swoich najlepszych pracowników jako nagroda za dobre wyniki w pracy. Głównie są to grupy 10-15-osobowe, które przyjeżdżają do Brazylii na kilka dni. Pełny program pobytu oraz kosztorys przygotowują właścicielki biura, one też zazwyczaj obsługują taką grupę i opiekują się klientami przez cały czas trwania wycieczki. Poza zwiedzaniem Rio de Janeiro osoby te często udają się do wodospadów Iquaçu, do Salwadoru, Amazonii czy Urugwaju.

Poza grupami zorganizowanymi właścicielki Samba Smile Travel obsługują indywidualnych turystów. W tabeli 4 pokazano liczbę klientów indywidualnych obsłużonych przez Samba Smile Travel w roku 2018.

Tabela 4. Liczba indywidualnych klientów obsłużonych przez Samba Smile Travel w 2018 r.

\begin{tabular}{|l|c|}
\hline \multicolumn{1}{|c|}{ Miesiąc } & $\begin{array}{c}\text { Liczba indywidualnych } \\
\text { klientów w 2018 r. }\end{array}$ \\
\hline Styczeń & 180 \\
\hline Luty & 90 \\
\hline Marzec & 70 \\
\hline Kwiecień & 29 \\
\hline Maj & 50 \\
\hline Czerwiec & 30 \\
\hline Lipiec & 50 \\
\hline Sierpień & 108 \\
\hline Wrzesień & 30 \\
\hline Październik & 20 \\
\hline Listopad & 180 \\
\hline Grudzień & 50 \\
\hline
\end{tabular}

Źródło: opracowanie własne na podstawie przeprowadzonych badań 
Oferowane przez biuro jednodniowe wycieczki to głównie wycieczki po Rio de Janeiro. Najbardziej popularnymi obiektami, które turyści chcą zobaczyć w tym mieście, są: pomnik Chrystusa Odkupiciela, stadion Maracanã, Głowa Cukru, Sambadrom oraz favele. W tabeli 5 zestawiono najpopularniejsze oferty jednodniowych wycieczek po Rio de Janeiro oferowanych przez Samba Smile Travel.

Tabela 5. Programy jednodniowe w Rio de Janeiro oferowane przez Samba Smile Travel

\begin{tabular}{|l|l|l|l|}
\hline \multicolumn{1}{|c|}{$\begin{array}{c}\text { Opcja pierwsza: } \\
\text { program } \\
\text { standardowy }\end{array}$} & \multicolumn{1}{|c|}{$\begin{array}{c}\text { Opcja druga: } \\
\text { program historyczny }\end{array}$} & \multicolumn{1}{|c|}{$\begin{array}{c}\text { Opcja trzecia: } \\
\text { program natura }\end{array}$} & \multicolumn{1}{|c|}{$\begin{array}{c}\text { Opcja czwarta: } \\
\text { Santa Teresa }\end{array}$} \\
\hline Chrystus Odkupiciel & Chrystus Odkupiciel & Chrystus Odkupiciel & Chrystus Odkupiciel \\
\hline Maracanã & Cinelandia & $\begin{array}{l}\text { wodospad w parku } \\
\text { Tijuca }\end{array}$ & wzgórze Santa Teresa \\
\hline Sambodrom & lunch & ogród botaniczny & lunch \\
\hline lunch & $\begin{array}{l}\text { rejs statkiem na wyspę } \\
\text { Ilha Fiscal }\end{array}$ & lunch & Park Ruin \\
\hline $\begin{array}{l}\text { przejazd przez } \\
\text { historyczne centrum }\end{array}$ & Praça XV & Vista Chinesa & Chácara do Céu \\
\hline Głowa Cukru & $\begin{array}{l}\text { spacer po Boulevard } \\
\text { Olimpico }\end{array}$ & $\begin{array}{l}\text { plaża Ipanema, } \\
\text { Copacabana }\end{array}$ & $\begin{array}{l}\text { schody Selarona, } \\
\text { akwedukt Arcos da } \\
\text { Lapa }\end{array}$ \\
\hline
\end{tabular}

Źródło: opracowanie własne na podstawie przeprowadzonych badań

Biuro w swojej ofercie ma także rozbudowany trzydniowy program zwiedzania Rio de Janeiro (tabela 6), który cieszy się dużą popularnością wśród klientów z Polski.

Tabela 6. Trzydniowy program zwiedzania Rio de Janeiro

\begin{tabular}{|l|l|l|}
\hline \multicolumn{1}{|c|}{ Dzień 1 } & \multicolumn{1}{c|}{ Dzień 2 } & \multicolumn{1}{c|}{ Dzień 3 } \\
\hline Chrystus Odkupiciel & Jeep tour - Floresta da Tijuca & $\begin{array}{l}\text { przejazd przez Ipanema, } \\
\text { Leblon }\end{array}$ \\
\hline lunch w Santa Teresa & lunch w ogrodzie botanicznym & Muzeum Casa do Pontal \\
\hline schody Selarona & ogród botaniczny & destylarnia Cachaça Maxicana \\
\hline $\begin{array}{l}\text { przejazd przez historyczne } \\
\text { miasto }\end{array}$ & przejazd przez Copacabanę & lunch \\
\hline Maracanã & Głowa Cukru & plaża Grumari \\
\hline Muzeum Samby & Ginga Tropical & kolacja \\
\hline
\end{tabular}

Źródło: opracowanie własne na podstawie przeprowadzonych badań

Właścicielki Samba Smile Travel w swojej ofercie mają również jednodniowe nurkowanie w zależności od stopnia zaawansowania klientów oraz piesze wędrówki po Rio de Janeiro. Do wyboru są dwie całodzienne trasy, w zależności od stopnia trudności i wielkości grupy. Trasa łatwiejsza, dla maksymalnie 12 osób, obejmuje wędrówkę do lasu deszczowego, Floresta da Tijuca (Szczyt Tijuca, wodospad Das Almas) oraz Wzgórze Dwóch Braci połączone ze zwiedzaniem faveli Vidigal oraz odwiedzeniem skały Bonita. Trasa trudniejsza, dla mniejszej liczby uczestników (maksymalnie 6 osób) obejmuje: skałę Gavea oraz Barra de Guaratiba - najodleglejszy południowy zakątek Rio de Janeiro położony u wybrzeża oceanu. 
Oferta Simba Smile Travel obejmuje także trzydniowe wycieczki do Parany oraz dwudniową wycieczkę (w dwóch różnych wersjach) na wyspę Ilha Grande, a także do Búzios, Petrópolis oraz Saquarema. Za pośrednictwem opisywanego biura można pojechać także do Foz do Iquaçu oraz do Minas Gerais. W ostatnim czasie popularne stały się wycieczki po brazylijskich favelach. Taką ofertę dla swoich klientów posiada również opisywane biuro.

Jak podkreślają właścicielki Simba Smile Travel, z roku na rok przybywa im klientów, wracają też do nich osoby, które korzystały już wcześniej z ich oferty. Biuro często obsługuje również klientów, którym jego usługi zostały polecone przez inne osoby, np. korzystające wcześniej z proponowanych przez nie wycieczek w Rio de Janeiro.

Drugim polskim biurem działającym w Rio de Janeiro jest biuro Brazylia Tour. Jest to filia działającego od ponad 10 lat na rynku brazylijskim biura pielgrzymkowego Pallotti Tour. Brazylia Tour organizuje wyjazdy indywidualne (m.in. wyjazdy rodzinne, podróże poślubne) i grupowe. Pomaga w rezerwacji hoteli i przygotowuje propozycje ciekawych wycieczek fakultatywnych. Podobnie jak Samba Smile Travel głównie obsługuje klientów z Polski przyjeżdzających na wakacje do Brazylii. Często są to także klienci z Europy oraz USA.

Oferowane przez biuro programy wyjazdów można modyfikować oraz dostosować do grupy, a także rozszerzyć o inne kraje (np. Argentyna, Paragwaj) lub pobyt wypoczynkowy. Każdy wyjazd omawiamy jest wcześniej z klientem, a program dostosowywany jest do jego potrzeb. Brazylia Tour jest bezpośrednim, lokalnym organizatorem wyjazdów pielgrzymkowych, wypoczynkowych oraz motywacyjnych. Współpracuje także z biurami podróży, agentami turystycznymi i parafiami. Biuro organizuje także wyjazdy do innych krajów Ameryki Południowej, m.in.: Boliwii, Argentyny, Chile i Paragwaju.

Największą popularnością wśród oferty biura cieszą się jednodniowe wycieczki po Rio de Janeiro. W tabeli 7 przedstawiono ich przykłady wraz cenami za osobę.

Tabela 7. Wybrane fakultatywne wycieczki organizowane przez Brazylia Tour

\begin{tabular}{|l|c|}
\hline \multicolumn{1}{|c|}{ Wycieczka } & Cena w dol. USA/os. \\
\hline Chrystus Odkupiciel & 160 \\
\hline Głowa Cukru & 205 \\
\hline Rio de Janeiro - city tour & 160 \\
\hline Rio de Janeiro - plaże & 160 \\
\hline Petrópolis - imperialne miasto & 120 \\
\hline Niterói - Do caminho Niemeyer as Praias Oceânica & 100 \\
\hline Búzios & 145 \\
\hline Aparecida - sanktuarium maryjne & 180 \\
\hline
\end{tabular}

Źródło: opracowanie własne na podstawie przeprowadzonych badań

Brazylia Tour w swojej ofercie ma także długie zagraniczne wycieczki. Jedną z nich jest trwająca 15 dni wycieczka zatytułowana „Kolonialne miasta”, podczas której turyści zwiedzają następujące miejsca: Búzios - Rio de Janeiro - Paraty - Aparecida - Penedo São Lourenço - Caxambu - Ouro Preto - Mariana - Petrópolis. W ofercie biura znajduje się także 12-dniowa wycieczka „Brazylia w pigułce”, w ramach której można odwiedzić następujące miejsca: São Paulo - Aparecida - Penedo - Rio de Janeiro - wyspy tropikalne - Foz do Iguaçu. 
Do egzytycznych wyparw oferowanych przez opisywane biuro należy wycieczka „W serce Amazonii”. Wyprawa trwa 13 dni, a w jej trakcie poza Rio de Janeiro zwiedza się także Salvador, Manaus oraz Foz do Iguaçu.

Miłośnikom przyrody biuro Brazylia Tour oferuje 14-dniową wyprawę w „Krainie dzikiej przyrody”. Podczas tej wyprawy podróżni zwiedzają Rio de Janeiro, Paraty, Pantanal, Foz do Iguaçu oraz Salwador.

\section{Wnioski końcowe}

Ameryka Południowa jest dla Polaków miejscem równie egzotycznym co Afryka czy Azja. Informacje dotyczące tego kontynentu, a przede wszystkim znajdujących się tam państw, pojawiają się zarówno w prasie, jak i w telewizji, ale Brazylia wciąż pozostaje w oczach Polaków krajem drogim, niedostępnym, odległym i niebezpiecznym. Pomiędzy polskimi miastami a São Paulo czy Rio de Janeiro nie ma bezpośrednich połączeń lotniczych. W związku z tym połączenie Polski z Brazylią możliwe jest jedynie za pomocą przesiadki w jednym z europejskich lub amerykańskich miast. To także powoduje, że kraj ten jest postrzegany przez turystów jako daleki i „nietypowy” do zwiedzania.

W Brazylii spotyka się zarówno nowoczesne miasta, np. Rio de Janeiro, jak i małe miasteczka zagubione w amazońskiej dżungli. To kraj wielu kultur, uroków i tajemnic, który przyciąga z roku na rok coraz większą liczbę podróżnych, ale wielu turystów z Polski wciąż boi się wyjechać do niego na własną rękę. Dlatego duża część podróżnych, która zdecydowała się na wyprawę do Brazylii, korzysta z lokalnych ofert polskich biur podróży działających na terenie Brazylii.

Aby oferta biur podróży była atrakcyjna dla klienta, nie tylko pod względem finansowym, właściciele biur podróży muszą podejmować nowe i ciekawe inicjatywy związane z prowadzoną działalnością.

Przedsiębiorczość biur podróży działających w obszarze turystyki w ostatnich latach jest przedmiotem coraz większego zainteresowania. W turystyce innowacje i przedsiębiorczość dotyczą produktu, a także usług turystycznych. Rynkowi turystycznemu nie wystarcza dostarczenie jakichkolwiek dóbr i usług, muszą one być coraz lepsze, oryginalniejsze i coraz oszczędniejsze. Innowacje odnoszą tylko wtedy swój skutek, jeżeli są wdrażane w takim przedsiębiorstwie turystycznym, które cechuje dbałość o rozwijanie przedsiębiorczości organizacyjnej. Innowacyjność ofert turystycznych, kreatywność pracowników biur podróży i przedsiębiorczość całej organizacji turystycznej to działania, które prowadzą na szczyty popytu w konkurencyjnym otoczeniu.

Omówione biura podróży działające w Rio de Janeiro istnieją od kilku lat. Z roku na rok coraz większa liczba turystów korzysta z ich ofert. Każde z opisanych biur deklaruje, że swoją ofertę może przygotować pod konkretnego klienta ze wszystkimi jego wskazaniami i życzeniami. To świadczy o elastyczności oraz gotowości do podejmowania wyzwań.

Analizując dane Estudo da demanda turística internacional 2014-2018, można zauważyć, że ok. 30\% turystów podczas swojego pobytu w Brazylii nastawione jest głównie na wypoczynek i najchętniej spędza ten czas w Rio de Janeiro (Ministério do Turismo, 2020, 25 stycznia). Podczas kilkudniowego wypoczynku pojawia się wśród turystów chęć zobaczenia i zwiedzenia tego miasta. Dlatego, wychodząc naprzeciw potrzebom rynku, w ofertach opisywanych biur podróży w Rio de Janeiro znajduje się taki szeroki wachlarz 
jednodniowych wycieczek fakultatywnych z przewodnikami mówiącymi w ojczystym języku przybyłych z różnych stron świata turystów, w tym także z Polski. Analizując raporty turystyczne okazuje się, że ok. 25\% turystów podróżujących w celach biznesowych do Brazylii również zatrzymuje się w Rio de Janeiro. Stąd innowacyjne propozycje od polskich biur z Rio „szyte na miarę” dla biznesowych klientów z Polski oraz oferta turystycznej opieki nad biznesowymi turystami podczas ich pobytu w Brazylii.

\section{Literatura}

References

Alejziak, W. (2008). Metodologia badań w turystyce. W: R. Winiarski (red.), Turystyka w naukach humanistycznych. Warszawa: Wydawnictwo Naukowe PWN, 140-164.

Alejziak, W. (2005). Aktualny stan i perspektywy rozwoju badań naukowych nad turystyką. W: R. Winiarski, W. Alejziak (red.), Turystyka w badaniach naukowych. Kraków: AWF, Rzeszów: WSIZ, 275-299.

Andrews, S. (2007). Introduction to Tourism \& Hospitality Industry. New Delhi: Tata McGraw-Hill Publishing Company Ltd.

Anisef, P., Lanphier, M. (2003). The World in the City. Toronto, Buffalo, London: University of Toronto Press.

Brzozowski, J. (2008). Przebieg procesu asymilacyjnego Polonii brazylijskiej. Zeszyty Naukowe, 791, 101-117.

Byszewska-Dawidek, M., Łopaciński, K. (2013). Rynek biur podróży 2012. Raport. Warszawa: Instytut Turystyki Szkoły Głównej Turystyki i Rekreacji.

Grzelka, D. (1996). Lokalizacja biur podroży na terenie Łodzi. Turyzm, 6(1), 5-29.

Jasiński, M., Kowalski, M. (2007). Fałszywa sprzeczność: metodologia jakościowa czy ilościowa?. W: A. Haber (red.), Ewaluacja ex post. Teoria i praktyka badawcza. Warszawa: Polska Agencja Rozwoju Przedsiębiorczości, 97-114.

Kmiecik, S. (2016). Polonia brazylijska w publicystyce ks. Zdzisława Malczewskiego. Warszawa: Muzeum Historii Polskiego Ruchu Ludowego.

Konieczna-Domańska, A. (2008). Biura podróży na rynku turystycznym. Warszawa: PWN.

Konieczna-Domańska, A. (1999). Biura podróży na rynku turystycznym. Warszawa: PWN.

Kula, M. (2001). Polska diaspora w Brazylii. W: A. Walaszek (red.), Polska diaspora. Kraków: WL.

Legler, P. (1950). Das Rechnungswesen das Reisebüros ein Beitrag zur Lehre vom Rechnungswesen der Dienstleistungsbetriebe. Zurich: Juris-Verlag.

Łazarek, M., Łazarek, R. (2002). Gospodarka turystyczna. Wybrane zagadnienia. Warszawa: Wydawnictwo WSE.

Łukasiewicz, K. (2019). Znaczenie Polski na światowym rynku turystycznym. W: J. Kacperska (red.), Polska we wspótczesnych międzynarodowych stosunkach gospodarczych. Warszawa: Wydawnictwo SGGW, 103-114.

Mazurek, J. (2018). Przeobrażenie Polonii brazylijskiej i jej rola w stosunkach polsko-brazylijskich. Niepodległość i Pamięć, 25(4/64), 77-102.

Mazurek, J. (2006). Kraj a emigracja. Ruch ludowy wobec wychodźstwa chłopskiego do krajów Ameryki Łacińskiej (do 1939 roku). Warszawa: Biblioteka Iberyjska.

Malczewski, Z. (1995). Obecność Polaków i Polonii w Rio de Janeiro. Lublin: Oddział Lubelski Stowarzyszenia „Wspólnota Polska”.

Michalska-Dudek, I. (2017). Kształtowanie lojalności klientów biur podróży. Wrocław: Monografie i Opracowania Uniwersytetu Ekonomicznego we Wrocławiu, 264(379). 
Ministério do Turismo. (2020, 25 stycznia). Estudo da demanda turística internacional. 2014-2018. Pozyskano z: http://www.dadosefatos.turismo.gov.br/2016-02-04-11-54-03/demanda-tur\%C3\%ADstica-internacional.html

Przecławski, K. (1986). Humanistic foundations of tourism. Warszawa: IT.

Rapacz, A. (2007). Przedsiębiorstwo turystyczne. Warszawa: Difin.

Singh, L.K. (2008). Management of Travel Agency. Delhi: ISHA Books.

Warszyńska, J., Jackowski, A. (1979). Podstawy geografii turyzmu. Warszawa: l’WM.

Ziółkowska-Weiss, K. (2019), Działalnościpolskich biurpodróżyw Greater Toronto Area. Przedsiębiorczość - Edukacja [Entrepreneurship - Education], 15(2), 184-199.

Ziółkowska-Weiss. K. (2016). Znaczenie działalności polskich biur podróży w Chicago. Annales Universitatis Paedagogicae Cracoviensis Studia Geographica, 10, 66-82.

Kamila Ziółkowska-Weiss, dr, adiunkt, Uniwersytet Pedagogiczny im. Komisji Edukacji Narodowej w Krakowie, Instytut Geografii, Katedra Turystyki i Badań Regionalnych. Studiowała prawo oraz kulturoznawstwo na Uniwersytecie Jagiellońskim - specjalność mediteraneistyka. Jest absolwentką geografii z podstawami przedsiębiorczości, którą ukończyła na Uniwersytecie Pedagogicznym w Krakowie. Ukończyła podyplomowe studia na Uniwersytecie Ekonomicznym w Krakowie, na kierunku zarządzanie turystyką międzynarodową. W 2015 r. z wyróżnieniem obroniła pracę doktorską, tym samym uzyskując tytuł doktora nauk o Ziemi. Od 2012 r. pracuje w Katedrze Turystyki i Badań Regionalnych Uniwersytetu Pedagogicznego w Krakowie, gdzie prowadzi m.in. zajęcia z turystyki w Stanach Zjednoczonych Ameryki Północnej. Jest czynnym pilotem wycieczek i autorką kilkudziesięciu publikacji naukowych. Jej główne zainteresowania naukowe to Polonia w Ameryce Północnej i Południowej, turystyka kulturowa oraz mniejszości narodowe w Polsce i w Ameryce Północnej.

Kamila Ziółkowska-Weiss, Phd, graduate of Law and Culture studies at the Jagiellonian University and of Geography at the Pedagogical University of Krakow. She has graduated from postgraduate studies in international tourism management at the Cracow University of Economics. Since 2012 she has been a research worker, acting as an assistant in the department of Tourism and Regional Studies at the Pedagogical University of Krakow. She is an active tourist guide and the author of several academic publications. Her main academic interests are in cultural tourism, ethnic groups in Małopolska and Polish minority in North and South America.

ORCID: https://orcid.org/0000-0001-6575-5314

\section{Adres/Address:}

Uniwersytet Pedagogiczny w Krakowie

Instytut Geografii

Katedra Turystyki i Badań Regionalnych

ul. Podchorążych 2

30-084 Kraków, Poland

e-mail: kamila.ziolkowska-weiss@up.krakow.pl 